KREATIF

Jurnal Ilmiah

Prodi Manajemen Universitas Pamulang
ISSN: 2339-0689 (Print), ISSN 2406-8616 (Online)

Volume 7, No 1 Juni 2019, (Halaman 44-54)

Tersedia online di http://openjournal.unpam.ac.id/index.php/kreatif

\title{
PENGARUH PROMOSI DAN KUALITAS PELAYANAN TERHADAP KEPUASAN SERTA BERDAMPAK TERHADAP LOYALITAS PELANGGAN
}

\author{
Nurmin Arianto \\ Program Studi Manajemen \\ Universitas Pamulang \\ dosen01118@unpam.ac.id
}

\begin{abstract}
ABSTRAK
Tujuan penelitian untuk menganlisa model pengembangan loyalitas berdasarkan promosi dan kualitas pelayanan, penelitian ini dilakukan pada pelanggan PT MKP. Dengan model uji empiris menggunakan analisis regresi dengan software SPSS V25 dan Ms. Excel.

Sampel dalam penelitian ini menggunakan sampel jenuh dengan jumlah 121 . Teknikanalisidata dengan menggunakan path analysis. Menggunakandua model Regresi.

Hasil analisis bahwa promosi dan kualitas pelayanan berpengaruh positif dan signifkan terhadap kepuasan, promosi dan kualitas pelayanan berpengaruh positif dan tidak signifakan trhadap loyalitas serta kepuasan berpengaruh positif dan signifikan terhadap loyalitas.
\end{abstract}

Kata Kunci : Promosi, Kualitas Pelayanan, Kepuasn pelanggan, Loyalitas pelanggn.

\section{ABSTRACT}

The research objective is to analyze the loyalty development model based on promotion and service quality, this research was conducted on the customers of PT MKP. With the empirical test model using regression analysis with SPSS V25 and Ms. software. Excel.

The sample in this study used a saturated sample with a total of 121. Data analysis using path analysis. Use two Regression models.

The results of the analysis that the promotion and quality of service have a positive and significant effect on satisfaction, promotion and quality of service have a positive and not significant effect on loyalty and satisfaction have a positive and significant effect on loyalty.

Keywords: Promotion, Service Quality, Customer Satisfaction, Customer Loyalty.

\section{PENDAHULUAN}

\section{A. Masalah Penelitian}

PT Mukti Karya Persada bergerak di bidang jasa percetakan yang berupaya untuk memenuhi kebutuhan pelanggannya melalui penawaran seperti melayani cetak blangko, nota, kwitansi, map, brosur, leaflet, kartu nama, ID card, undangan, kalender, poster, majalah, tabloid, buku agenda dan paper bag. Sedangkan digital printing antara lain baleho, stiker dan X/rol Banner. Dengan disediakannya berbagai macam jasa percetakan, maka konsumen dengan mudah memilih jenis jasa yang ingin digunakannya sesuai dengan kebutuhan. Adapun media promosi yang digunkan oleh PT MKP adal dengan menggunakan Internet marketing seperti website dan media sosial serta memberikan brosur kepada consumen yang datang ke workshop untuk melihat langsung, namun akhir-akhir ini promosi yang digunakan 
oleh perusahan masih kurang efektif hal ini bisa dilihat dari data jumlah pelanggan yang menggunakan jasa percetakan di perusahaan mengalami penurunan dan kurang nya kemampuan untuk meyakinkan pelanggan tentang jasa yang disediakan oleh perushaan, selain promosi yang digunakan perusahaan masih kurang, kualitas pelayanan yang diberikan oleh PT MKP juga masih kurang hal ini bisa dilihat dari cetakan normal PT MKP selesai dalam 3 hari s/d 1 minggu terhitung dari awal pesanan. Pesanan normal berupa pembuatan leaflet, brosur, poster, stiker, map, kop surat, majalah, tabloid dan bulletin. Sedangkan untuk pemesanan kalender, buku agenda dan paper bag membutuhkan waktu 2 minggu untuk penyelesaiannya. Selanjutnya untuk pemesanan berupa undangan hard cover dengan menggunakan tinta emas dalam penyelesaiannya membutuhkan waktu \pm 2 bulan. Sedangkan minimal order cetakan yang ada di PT MKP adalah cetakan brosur/leaflet dan cetakan yang sifanya full colour minimal 2000 lembar A4 per orderan.

Tabel 1

Jenis Cetakan

\begin{tabular}{|l|l|c|}
\hline $\begin{array}{c}\text { Jenis } \\
\text { Cetakan }\end{array}$ & \multicolumn{1}{|c|}{ Finishing } & Waktu Kerja \\
\hline Brosur & Lipat\&sisir & $\begin{array}{c}\text { 3 hari s/d 1 } \\
\text { minggu }\end{array}$ \\
\hline Stiker & Laminating\&Pond & $2-3$ Hari \\
\hline Map & Sisir & \\
\hline Poster & Laminating\&sisir & \multirow{2}{*}{2 minggu } \\
\hline $\begin{array}{l}\text { Buku/Maja } \\
\text { lah }\end{array}$ & $\begin{array}{l}\text { Jahit Kawat,Lem Panas,Jahit } \\
\text { Benang,Wrapping }\end{array}$ & \\
\hline Paperbag & Laminating,Pond,Mata Ayam & \\
\hline Kalender & $\begin{array}{l}\text { Jepit Kaleng,Spiral,Mata } \\
\text { Ayam }\end{array}$ & \\
\hline
\end{tabular}

\section{Sumber: PT MKP}

Dari tabel tersebut dapat diketahui jenis pekerjaan yang di berikan oleh PT MKP diantaranya adalah jasa pembuatan brosur yang di estimasi dalam waktu pengerjaanya 3 sampai dengan 1 minggu tergantung tingkat kesulitan dan banyak nya jumlah brosur yang dipesan. Maka dari itu waktu yang di estimasi untuk proses pengerjaanya dapat mempengaruhi kualitas pelayanana yang diberikan oleh PT MKP kepada pelanggan nya, dimana kualitas pelayanan bisa dikatakan berkualitas atau tidak tergantung pada penilain dari pelayanan yang diberikan. Kualitas pelayanan yang ada di PT MKP dikatakan masih kurang dimana dapat dilihat dari tabel 1.2 tentang keluhan pelanggan.

Tabel1.2

Data Keluhan pada PT Mukti Karya Persada

\begin{tabular}{|c|l|c|}
\hline NO & \multicolumn{1}{|c|}{ JENIS KELUHAN } & $\begin{array}{l}\text { JUMLAH } \\
\text { ORANG }\end{array}$ \\
\hline 1 & Kurangnya fasilitas untuk finishing & 10 orang \\
\hline 2 & Ongkos cetak yang mahal & 12 orang \\
\hline 3 & $\begin{array}{l}\text { Bahan baku kertas terbatas, } \\
\text { sehingga pelanggan harus membawa kertas } \\
\text { sendiri }\end{array}$ & 8 orang \\
\hline 4 & $\begin{array}{l}\text { Kurang teliti dalam finishinkomplit } \\
\text { buku/majalah }\end{array}$ & 20 orang \\
\hline 5 & Terbatasnya tenaga kerja dalam pengiriman & 17 orang \\
\hline
\end{tabular}




\begin{tabular}{|c|l|c|}
\hline 6 & $\begin{array}{l}\text { Kurang teliti untuk bagian design, pernah } \\
\text { terjadi kesalahan tulisan huruf maupun angka }\end{array}$ & 15 orang \\
\hline
\end{tabular}

\section{Sumber: PT MKP Januari-Maret}

Dari tabel tersebut dapat dilihat bahwa di dimonasi oleh kurang telitinya petugas dalam membuat desian dimana sebanyak 20 orang kemudian di susul oleh tenaga kerja yang terbatas dalam pengiriman sebanyak 17 orang sehingga pelayanan yang di berikan dirasa masih kurang oleh pelanggan yang menggunakan jasa percetakan di PT MKP maka dari itu diperlukan analisis agar kualitas pelayann yang diberikan ssuai dengan harapan pelanggan sehingga dpat menyebabkan pelanggan yang merasa puas dan berdampak terhadap loyalitas, dimana kepuasan adalah perasaan kepuasan / kekecewaan yang dihasilkan dari perbandingan antara kinerja suatu produk atau hasil yang diperoleh dan harapan. Jika kinerjanya di bawah harapan, pelanggan akan kecewa dan, jika ini memenuhi harapan konsumen, mereka akan puas.

Di bawah ini adalah jumlah pelanggan yang menggunakan jasa percetakan PT MKP tahun 2016-2017.

Tabel 1.3

Data Pelanggan PT MKP Januari-Maret

\begin{tabular}{|c|c|c|}
\hline No & Bulan & $\begin{array}{c}\text { Jumlah } \\
\text { Pelanggan }\end{array}$ \\
\hline 1 & Jan & 154 \\
\hline 2 & Feb & 122 \\
\hline 3 & Mar & 121 \\
\hline \multicolumn{2}{|c|}{ Total } & 397 \\
\hline
\end{tabular}

Sumber : PT MKP

Berdasarkan data tabel di atas, maka data tersebut menunjukkan adanya penurunan jumlah pelanggan setiap tahunnya, hal ini dikerenakan mash terdapat pelanggan yang merasa tidak puas sehingga dengan kondisi yang mengalami sedikit penurunan. Jadi perusahaan harus mempertahankan pelanggan yang sudah ada dan mencari pelanggan lain. Jadi itu tidak mudah, karena ada banyak alasan mengapa faktor-faktor ini terjadi dalam bentuk perusahaan jasa berkualitas tinggi kepada pelanggan. PT MKP telah memaksimalkan dimensi pelayanannya, namun demikian masih terdapat aspek layanan yang perlu diperhatikan yaitu kurangnya tenaga desain grafis sehingga jika konsumen yang datang secara bersamaan dan membutuhkan desain cepat, maka konsumen harus menunggu terlebih dahulu. Pelanggan yang puas akan berkibat terhadap loyalitas pelanggan dimana konsumen yang melakukan pembelian secara berulang terkait dengan merek dan produk yang sama secara berulang hal ini karena hanya satu satu nya merk yang tersedia, merk termurah dan sebagainya. Berdasarkan obervasi yang di lakukan sebelumnya masih terdapat pelanggan yang beralih kepercetakan lain hal ini dikarenakan pelanggan merasa kecewa dan tidak puas dengan hasil percetakan yang diberikan oleh PT Mukti Karya Persada, sehingga diperluka evaluasi agar meningkatkan loyalitas pelanggan terhadap perusahaan.

Dengan latar belakang di atas dan melihat pentingnya kualitas pelayanan dan kepuasan pelanggan sehingga memiliki pengaruh terhadap loyalitas pelanggan maka menarik untuk diteliti dengan judul "Pengaruh Promosi dan Kualitas Pelayanan Terhadap Kaepuasan Serta Berdampak Pada Loyalitas Pelanggan pada PT MKP”. 


\section{B. Pokok-pokok Permasalahan}

Melihat uraian pada bab pendahuluan, maka penelitian ini berfokus tetang permasalahan

- pemasalahan yaitu :

1. Bagaimana pengaruh promosi $\left(\mathrm{X}_{1}\right)$ terhadap kepuasan $\left(\mathrm{Y}_{1}\right)$

2. Bagaimana pengaruh kualitas pelayanan $\left(\mathrm{X}_{2}\right)$ terhadap kepuasan $\left(\mathrm{Y}_{1}\right)$

3. Bagaimana pengaruh promosi $\left(\mathrm{X}_{1}\right)$ terhadap loyalitas $\left(\mathrm{Y}_{2}\right)$

4. Bagaimana pengaruh kualitas pelayanan $\left(\mathrm{X}_{2}\right)$ terhadap loyalitas $\left(\mathrm{Y}_{2}\right)$

5. Bagaimana pengaruh kepuasan $\left(\mathrm{Y}_{1}\right)$ terhadap loyalitas $\left(\mathrm{Y}_{2}\right)$

\section{KAJIAN PUSTAKA}

\section{A. Promosi}

Buchari Alma (2016:179) yang mengatakan bahwan promosi merupakan sejins komunikasi yang memberi penjelasak yang meyakinkan calon konsumen tentang barang dan jasa. Tujuan promosi ialah memperoleh perhatian, mendidik, mengingatkan dan meyakinkan calon konsumen. Untuk mengukur promosi menurut Koter dan Amstrong (2012:413) yaitu periklanana, promosi penjualan, penjualan pribadi, hubungan masyrakat, pemasaran langsung.

\section{B. Kualitas Pelayanan}

Kualitas pelayanan merupakan kegiatan yang unggul dan diharapkan didalam memenuhi ekpestasi dan keingina pelanggan yang disertai kemudahan dalm memenuhi kebutuhan mereka sehingga pelanggan akan merasa snang.

Sedangakan indikator yang di gunakan untuk mengukur kualitas pelayanan menurut Parasuraman, Zeithaml, dan Berry (1985) yang dikutip oleh Fandy Tjiptono (2012:174) terdapat lima pokok untuk mengukur kualitas layanan. Lima pokok tersebut antara lain: Reliability, Responsiveness, Assurance, Empathy, Tangibles.

\section{Kepuasan Pelaggan}

Kepuasan adalah perasaan kepuasan / kekecewaan yang dihasilkan dari perbandingan antara kinerja suatu produk atau hasil yang diperoleh dan harapan. Jika kinerjanya di bawah harapan, pelanggan akan kecewa dan, jika ini memenuhi harapan konsumen, mereka akan puas.

Jadi kepuasan konsumen adalah fungsi dari persepsi atas kinerja dan keinginan. Apabila hasil yang diinginkan berada dibawah keinginan, maka akan merasa tak puas. Apabila kinerja yang diberikan sesuai dengan keinginan, pelanggan dapat merasa puas. Apabila kinerja yang diberikan melebihi keinginan pelanggan amat puas atau senang.

Begitu banyak perusahaan yang berfokus pada kepuasan besar karena pelanggan yang kepuasannya adalah tempat yang sempurna untuk mengubah pikiran mereka ketika mereka mendapatkan kesepakatan yang lebih baik. Mereka yang sangat puas lebih sulit untuk mengubah pilihan mereka. Zeithmal dan Bitner dalam Jasfar (2012:20), terdapat lima faktor yang dapat mempengaruhi kepuasan pelanggan, sebagai berikut: Aspek barang dan jasa, Aspek emosi pelanggan, Aspek pengaruh kesuksesan atau kegagalan jasa, Aspek persepsi atas persamaan atau keadilan, Aspek pelanggan lain, keluarga, dan rekan kerja.

\section{Loyalitas Pelanggan}

Loyalitas adalah "Perilaku pembelian berulang sehubungan dengan pembelian merek tertentu dan hal yang sama secara berulang (ini mungkin 
karena hanya ada satu merek yang tersedia, merek termurah , dll., Tjiptono (2011: 481).

Dari wawasan di atas dapat disimpulkan bahwa loyalitas adalah adalah hasil yang diperoleh dari kepuasan pelanggan dengan suatu produk atau produk layanan, loyalitas ini memiliki pengaruh positif terhadap perusahaan seperti pelanggan setia yang melakukan pembelian berulang-ulang terhadap produk perusahaan.

Kotler \& Keller (2012: 57) menyarankan beberapa indikator loyalitas konsumen: pembelian berulang, retensi, referensi.

\section{E. Kerangka Berfikir Penelitian}

Kerangka berpikir menunjukkan bahwa keadaan pikiran adalah konsep tentang bagaimana teori mengikat dan mempengaruhi

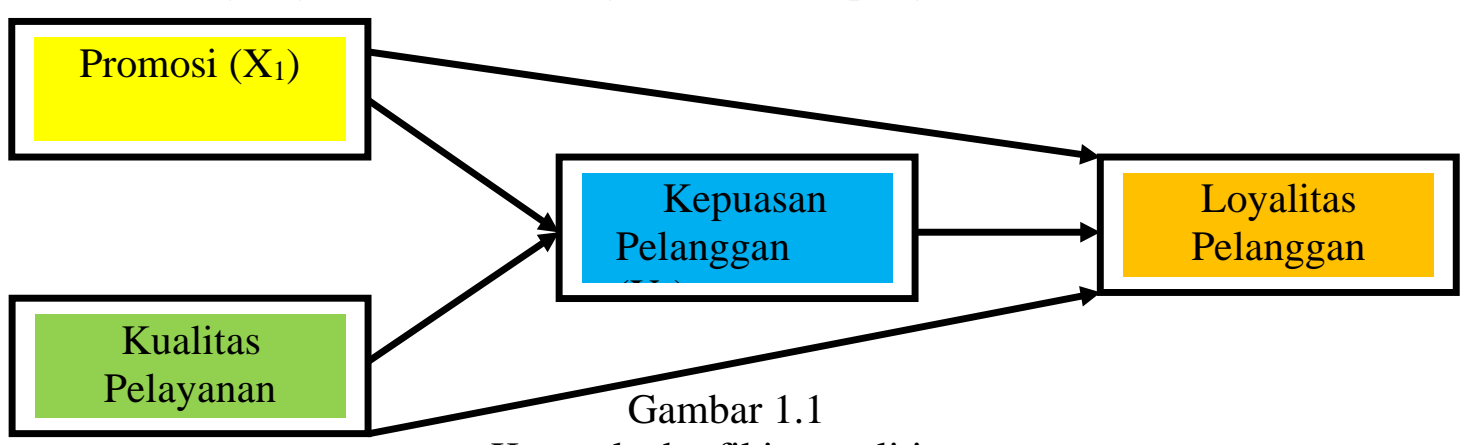

\section{F. Hipotesis}

Kerangka berfikir penelitian

Hipotesis pada dasarnya adalah jawaban sementara dari rumusan masalah yang diajukan dalam sebuah penelitian yang akan dijalakan oleh peneliti, maka dari itu hipotesis yang diajukan dalam penelitian ini adalah:

$\mathrm{Ha}_{1}$ : Terdapat pengaruh yang positif yang signifikan antara promosi terhadap kepuasan pelanggan

$\mathrm{Ha}_{2}$ :Terdpaat pengaruh positif yang signifikan antara kualitas pelayanan terhada kepuasan pelanggan

$\mathrm{Ha}_{3}$ :Terdapat pengaruh positif yang signifikan antara promosi terhadap loyalitas pelanggan

$\mathrm{Ha}_{4}$ :Terdapat pengaruh positif yang signifikan antara kualitas pelayanan terhadap loyalitas pelanggan

$\mathrm{Ha}_{5}$ :Terdapat pengaruh positif yang signifikan antara kepuasan terhadap loyalitas pelanggan

\section{METODE PENELITIAN}

\section{A. Sifat penelitian}

Riset yang digunakan dalam penelitian ini adalah dengan asosiatif, dimana penelitian yang ditujukan untuk mengetahui pengaruh atau hubungan dua variabel atau lebih variabel yang diteliti, dalam penelitian yang dijalankan ini menggunkan Asosiatif dimana untuk mengetahui pengaruh variabel promosi dan variabel kualitas pelayanan terhadap kepuasan dan dampaknya pada loyalitas pelanggan pada PT MKP.

\section{B. Populasi Dan Sampel}

Populasi penelitian ini adalah pelanggan jasa percetakan di PT MKP sebanyak 121 pelanggan. Dan teknik sampling yang digunakan adalah sampling Jenuh. Dalam penelitian ini penulis tidak menentukan banyaknya sampel, karena seluruh anggota populasi akan ditelit yaitu sebanyak 121 pelanggan. 


\section{Analisis Data}

Instrumen penelitian akan digunakan untuk melakukan pengukuran dengan tujuan menghasilkan data kuantitatif yang akurat. Hasil perhitungan dari skor atau nilai kemudian digunakan dalam analisis statistik yang dilakukan dengan analisis regresi sederhana. Uji korelasi product moment, koefisien determinasi dan uji hipotesis (uji t).

\section{ANALISISA DATA}

Analisa data yang digunakan adalah analisa deskriptif dan analisa statistic infrensial dimana untuk mengetahui bayangan umum respnden dan menjawab pertanyaan yang diajukan dalam sebuah penelitian dengan cara menganalisa serta menguji model tersebut secara empiris dengan menggunakan multiple regression dan program SPSS V. 22.

\section{A. Hasil Analisis}

Dari hasil penyebaran kusioner yang dilakukan kepada responden maka dapat diketahi mayoritas usis respnden dalam penelitian in adalah usi 26-35 tahun yaitu sebanyak 65\%, sedangakan jenis kelaminya adalah laki-laki yaitu sebnayan $63 \%$, lalu dengan pendidikan terkahir S1 yaitu sebnayak $45 \%$ dan dilihat dri frekuensi maka mayoritas lebih dari 2x yaitu sebesar $67 \%$.

B. Uji Validitas dan Uji Reliabilitas

Uji validitas: Angka korelasi yang diperoleh > daripada nilai standar maka pertanyaan tersebut valid. Dimana nilai $r$ hit untuk variabel promosi yaitu bekisar anatara $0,824 \mathrm{~s} / \mathrm{d} 0,831$, variabel kualitas pelayanan $0,851 \mathrm{~s} / \mathrm{d} 0,836$, variabel kepuasan pelanggan $0,843 \mathrm{~s} / \mathrm{d} 0,610$ serta variabel loyalitas pelanggan $0,653 \mathrm{~s} / \mathrm{d}$ 0,709 dan semua nilai nya $>\mathrm{r}$ table yaitu 0,3 sehingga semua pertnyataan dikatakan valid dan sejalan dengan teori Sugiyono (2017:125).

Uji reliablistas:

Reliabiltas merupakan pengkuran terhadap kuisioner yang di buat kepada yang sama sehingga menghasilkan hasil data yang sama. Maka syarat uji rleibilitas dalam penelitian ini adalah 0,6, Sugiyono (2013:184). Didalam penelitian ini maka dilihat dari nilai alpha cronbach dimana unutk variabel promosi memiliki nilai 0,944 , varibael kualitas pelayanan 0,907 , variabel kepuasan pelangggan 0,923 dan variabel loyalitas pelanggan memiliki nilai 0,853 sehingga seluruh nilia tersebut diatas nilai $r$ tabe yaitu 0,6 maka dari itu seluruh variabel tersebut dinyatakan reliable.

C. Analisis Rgresi Linier Berganda (Persamaan structural 1)

\section{Regresi linear berganda}

\section{Selanjutnya diuji model 1 dengan regresi berganda:}

Tabel 1.1

Regresi Berganda Persamaan ke I

Coefficients $^{\mathrm{a}}$

\begin{tabular}{|c|c|c|c|c|c|c|}
\hline \multirow[b]{2}{*}{ Model } & & \multicolumn{2}{|c|}{ Unstandardized Coefficients } & \multirow{2}{*}{$\begin{array}{l}\text { Standardized } \\
\text { Coefficients } \\
\text { Beta }\end{array}$} & \multirow[b]{2}{*}{$\mathrm{t}$} & \multirow[b]{2}{*}{ sig. } \\
\hline & & B & Std Error & & & \\
\hline \multirow[t]{3}{*}{1} & (Constant) & 7.493 & 1.824 & & 4.108 & .000 \\
\hline & $x_{1}$ & 476 & 125 & .518 & 3.812 & .000 \\
\hline & $x_{2}$ & .354 & .139 & .346 & 2.545 & .012 \\
\hline
\end{tabular}

Sumber: Data Primer yang dioleh, 2019 
Dari table di atas diperoleh persamaan regresi berganda yaitu: $\mathrm{Y}_{1}=0,518 \mathrm{X}_{1}+0,346 \mathrm{X}_{2}$

Dari persamaan tersebut maka nilai cofficients standardized 0,518 untuk variabel promosi dan 0,346 buat variabel kualitas pelayanan, sehingga dapat diketahui bahwa promosi dan kualitas pelayanan memilki pengaruh yang positif terhada kepuasan pelanggan, dimana semakin baik promosi yang diberikan perusahaan dan semakain baik kualitas pelayanan yang diberikan makan akan semakin berdampak positif bagi kepuasan pelanggan. Promosi yang diberikan perusahaan memilikii pengaruh yang lebih kuat terhadap kepuasan dibanding dengan kualitas pelayanan yang diberikan hal ini dikarenakan media promosi yang digunakan perusahaan sudah berjalan dengan baik dan maksimal dan ketepan waktu dalam memberikan pesanan pelanggan juga sudah baik, maka dari itu untuk meningkatkan kepuasan pelanggan dibutuhkan promosi dan kualitas pelayanan yang baik

2. Uji kelayakan model (Koefisien Determinasi)

\section{Tabel 1.2}

\section{Koefisien Determinasi}

\begin{tabular}{|c|c|c|c|c|}
\hline \multicolumn{5}{|c|}{ Model Summary } \\
\hline Model & $R$ & R Square & $\begin{array}{c}\text { Adjusted R } \\
\text { Square }\end{array}$ & $\begin{array}{l}\text { Std. Error of } \\
\text { the Estimate }\end{array}$ \\
\hline 1 & $.851^{a}$ & .724 & .719 & 4.288 \\
\hline
\end{tabular}

Sumber: Data Primer yang dioleh, 2019

Jika dilihat table 1.2 maka diperoleh nilai adjusted $r$ square sebesar 0,719 , hal ini promosi dan kualitas pelayanan memiliki kontribusi terhadap kepuasan pelanggan sebsar $71,9 \%$ atau perubahan yang terdapat pada kepuasan dapat dijelaskan oleh promosi serta kualitas pelayanan, sedangakan sisanya sebsar $28,1 \%$ dipengaruhi oleh faktor lain yang tidak diteliti oleh penulis seperti harga, lokasi dan lainya.

3. Uji Signifikan (Uji Annova)

Tabel 1.3

Uji F (Annova)

\begin{tabular}{|c|c|c|c|c|c|c|}
\hline \multicolumn{7}{|c|}{ ANOVA $^{\mathrm{a}}$} \\
\hline Madel & & $\begin{array}{l}\text { Sum of } \\
\text { Squares }\end{array}$ & $d f$ & Mean Square & $\mathrm{F}$ & Sig. \\
\hline \multirow[t]{3}{*}{1} & Regression & 5685.266 & 2 & 2842.633 & 154.575 & $.000^{\mathrm{b}}$ \\
\hline & Residual & 2170.023 & 118 & 18.390 & & \\
\hline & Total & 7855.289 & 120 & & & \\
\hline
\end{tabular}

Sumber: Data Primer yang dioleh, 2019

Pada table 1.3 diketahui nilai $F$ hit sebsar 154,575 dan nilai $F$ sig 0,000 sehingga dapat dikatakan bawah nilai $\mathrm{F}_{\text {hit }}>\mathrm{F}_{\text {Tab }}$ dan Nilai $\mathrm{F}_{\text {sig }}<\mathrm{F} 0,05$, maka dapat disimpulkan nilai $154,575>3,073$ dan $0,000<0,05$ yang bermakna bahwa variabel 
promosi dan kualitas pelayanan secara simultan mempengaruhi kepuasan pelanggan sehingga hal ini dapat diartikan bahwa model yang memasukan variabel tersebut sudah tepat (goodness of fit).

D. Analisa Multiple Regression (Persamaan structural 2)

1. Regresi linear berganda

Tabel 1.4

Regresi Berganda Persamaan ke II

Coefficients $^{a}$

\begin{tabular}{|c|c|c|c|c|c|c|}
\hline & & \multicolumn{2}{|c|}{ Unstandardized Coefficients } & \multirow{2}{*}{$\begin{array}{c}\text { Standardized } \\
\text { Coefficients } \\
\text { Beta }\end{array}$} & \multirow[b]{2}{*}{$\mathrm{t}$} & \multirow[b]{2}{*}{ Sig. } \\
\hline \multicolumn{2}{|c|}{ Model } & B & Std. Error & & & \\
\hline \multirow[t]{4}{*}{1} & (Constant) & 8.337 & 1.074 & & 7.764 & .000 \\
\hline & $x_{1}$ & .014 & .073 & .018 & .191 & .849 \\
\hline & $x_{2}$ & .070 & .079 & .082 & .894 & .373 \\
\hline & $Y_{1}$ & .721 & .051 & .855 & 14.219 & .000 \\
\hline
\end{tabular}

a. Dependent Variable: $Y 2$

Sumber: Data Primer yang dioleh, 2019

Pada table 1.4 maka diperoleh persamaan regresi yaitu

sebesar : $\mathrm{Y}_{2}=0,018 \mathrm{X}_{1}+0,082 \mathrm{X}_{2}+0,855 \mathrm{Y}_{1}$

Berdasarkan table diatas maka dapat diketahui nilai cofficients standardized 0,018 untuk promosi, 0,082 untuk kualitas pelayanan dan 0,855 untuk kepuasan pelanggan. Sehinggan dapat dijelaskan promosi, kualitas pelayanan dan kepuasan memiliki pengaruh yang positif terhadap loyalitas, diaman semakin baik promosi, kualitas pelayanan yang diberikan akan mempengaruhi kepuasan pelanggan sehinng berdammpak terhadap loyalita pelanggan, pengaruh kepuasan terhadap loyalitas pelanggan hal ini disebabkan karena kompetensi yang dimiliki oleh perusahaan dan media promosi yang dijalankan sudah baik sehingga meningkatkan kepasan dan membangun loyalita pelanggan.

2. Uji kelayakan model ( Koefisien Determinasi)

Tabel 1.5 Koefisien Determinasi

\begin{tabular}{l|l|r|r|r}
\multicolumn{7}{c}{} & \multicolumn{3}{c}{ Model Summary } \\
Model & $R$ & R Square & $\begin{array}{c}\text { Adjusted R } \\
\text { Square }\end{array}$ & $\begin{array}{c}\text { Std. Error of } \\
\text { the Estimate }\end{array}$ \\
\hline 1 & $.940^{a}$ & .883 & .880 & 2.361 \\
\hline
\end{tabular}

a. Predictors: (Constant), $\mathrm{Y} 1, \mathrm{X}_{2}, \mathrm{X} 1$

b. Dependent Variable: $Y 2$

Sumber: Data Primer yang dioleh, 2019

Pada table diatas maka dapat diketahui nilai Adj r square yaitu sebesar 0,880, yang berate bahwa promosi, kualitas pelayanan dan kepuasan pelanggan memiliki kontribusi terhadap loyalotas pelanggan yaitu sebesar $88 \%$ dan sisanya $12 \%$ dipengaruhi oleh variabel lain yang tidak diteliti.

3. Uji Signifikan (Uji f) 
Tabel 1.6

Uji F (Annova)

\begin{tabular}{|c|c|c|c|c|c|c|}
\hline \multicolumn{7}{|c|}{ ANOVA $^{a}$} \\
\hline \multicolumn{2}{|c|}{ Model } & $\begin{array}{l}\text { Sum of } \\
\text { Squares }\end{array}$ & $d f$ & Mean Square & $\mathrm{F}$ & Sig. \\
\hline \multirow[t]{3}{*}{1} & Regression & 4925.750 & 3 & 1641.917 & 294.488 & $.000^{b}$ \\
\hline & Residual & 652.333 & 117 & 5.575 & & \\
\hline & Total & 5578.083 & 120 & & & \\
\hline
\end{tabular}

a. Dependent Variable: $Y 2$

b. Predictors: (Constant), $Y 1, X 2, X 1$

Sumber: Data Primer yang dioleh, 2019

Jiika dilihat pada table annova maka diperoleh nilai $\mathrm{F}_{\text {hit }}$ yaitu 294,488 dan nilai $\mathrm{F}_{\text {sig }}$ yaitu 0,000, sehingga dapat ditarik kesimpulan bawah nilai $\mathrm{F}_{\text {hit }}>\mathrm{F}_{\text {tab }}$ dan $\mathrm{F}_{\text {sig }}<0,05$, dengan dimikian 294,488 > 3,073 dan 0,000<0,05, memiliki makna variabel promosi dan kualitas pelayanan serta kepuasan pelanggan secara simultan mempengaruhi loyalitas pelanggan sehingga hal ini dapat diartikan bahwa model yang memasukan variabel tersebut sudah baik (gof / goodness of fit).

\section{E. Pengaruh Tidk Langsung Promosi, Kualitas Pelayanan Terhadap Loyalitas Melalui Kepuasan}

Untuk mengetahui pngaruh secara tidak langsung promosi dan kualitas pelayanan terhadap loyalitas melalui kepuasan dpat digunakan analisis jalur atau path analysis.

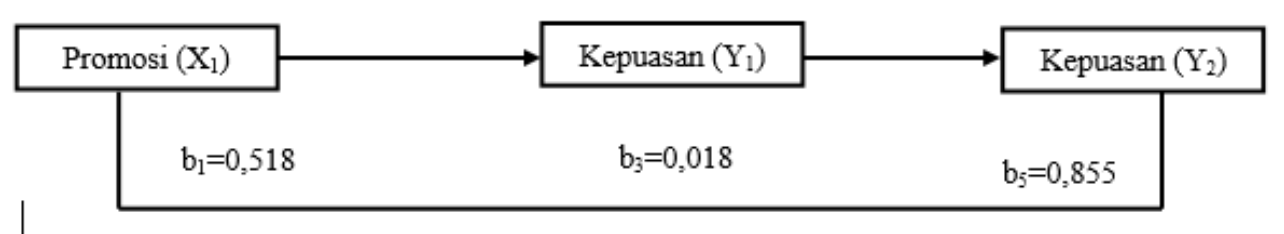

Gambar 1.1

Jalur path 1

Pengaruh langsung promsi terhadap loyalitas melalui perantara kepuasan adalah $\mathrm{b}_{1} \times \mathrm{b}_{5}=0,518 \times 0,855=0,443$. Hasil kali nilainya $>0,01\left(\mathrm{~b}_{3}\right)$ sehingg pengaruh perantara kepuasan berlaku bagi promosi terhadap loyalitas, maka dari itu kepuasan berfungsi sebagai variabel perantara anatara variabel promosi terhadap loyalitas pelanggan, promosi pun memiliki pengaruh langsung terhadp loyalitas (direct effect) dengan cofficients 0,018 (positif) sehngga total pengaruh (total effect) terhadap loyalitass yaitu $0,443+0,018=0,461$ (inderct effect + total effect).

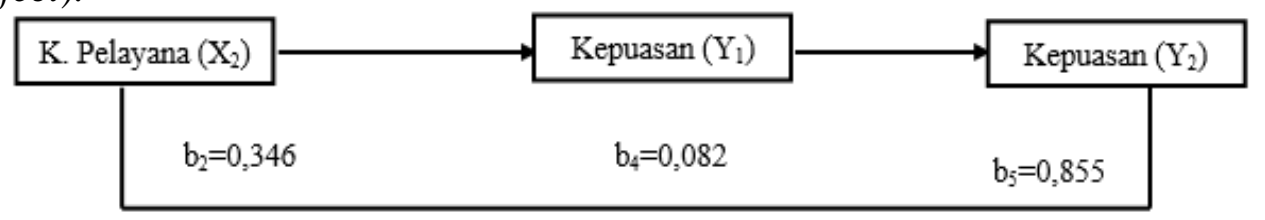

Gambar 1.2

Jalur path 2 
Pengaruh tidak langsung kualitas pelayanan terhadap loyalitas melalui mediasi kepuasan pelanggan adalah $b_{2} \times b_{5}=0,346 \times 0,855=0,296$. Hasil tersebut menunjukan nila 0,296 >0,082 $\left(\mathrm{b}_{4}\right)$ dengan demikian efek mediasi kepuasan berlaku bagi pengaruh kualitas pelayanan terhadap loyalitas pelanggan atau dengan kata laian kepuasan pelanggan berfungsi sebgaai variabel mediasi antara kepuasan pelanggan terhadap loyalitas pelanggan. Kepuasan pelanggan berpengaruh langsung terhadap loyalitas (direct effect) dengan koefisein 0,082 (positif) sehingga total pengaruh (total effect) kualitas pelayanan terhadap loyalitas pelanggan 0,296 +0,082 =0,378 (inderct effect + direct effect $)$.

\section{F. Uji Hipotesis}

1. Makin baik promosi, maka akan makin meningkatan kepuasan pelanggan Promotion memiliki pengaruh postif dimana nilai beta yaitu 0,518 dan signifikan terhadap kepuasan pelanggan dengan nilai $p=0,000$ dan $<$ 0,05 sehingga $\mathrm{Ha}_{1}$ diterima dimana bahwa semakin baik promosi maka kepuasan pelanggan akan meningkat. $\mathrm{Ha}_{1}$ ini sesuai dengan penelitian Siti (2014), dan Penelitian Khan et al. (2012) menemukan pengaruh positif dan signifikan variabel promosi terhadap variabel kepuasan pelanggan, sehingga semakin baik promosi yg dijalankan diharapkan memberikan dampak baik terhadap kepuasan.

2. Makin baik kualitas pelayanan, maka akan makin meningkatkan kepuasan pelanggan

Kualitas pelayanan memiliki pengaruh postitf dimana nilai beta yaitu 0,346 dan signifikansi terhadap kepuasan pelanggan dengan nnilai $p=0,012$ dan $<$ 0,05. Sehingga dapat dikatakan $\mathrm{Ha}_{2}$ diterima dimana semakin baik kualitas pelayanan, maka kepuasan pelanggan akan makin meningkat, hal ini sesuai dengan penelitian Anindya et al (2017) yang menyatakan bahwa semakin baik penilaian seseorang tentang kualitas layanan yang dimiliki cafe, maka semakin meningkat pula kepuasaan konsumen.

3. Makin baik promosi, maka akan makin meningkatkan loyalitas pelanggan Promosi memiliki pengaruh positif dimana nilai beta yaitu 0,018 dan tidak signifikan terhadap loyalitas pelanggan dengan nilai $p=0,849$ karena nilai tersebut $>0,05$. Sehingga dapat dikatakan bahwa $\mathrm{Ha}_{3}$ ditolak dimana semakin baik promosi yang dijalakan maka tidak berakibat terhadap loyalitas pelanggan.

4. Makin baik kualitas pelayanan, maka akan semakin meningkat loyalitas pelanggan

Kualitas pelayanan memiliki pengaruh positif dengan nilai beta yitu 0,082 dan tidak signifikan karena $p=0,373>0,05$ sehingga $\mathrm{Ha}_{4}$ ditolak dimana semakin baik kualitas pelayanan yang diberikan maka tidak meningkatkan loyalitas pelanggan secara signifikan.

5. Makin meningkat kepuasan, sehingga akan semakin meningkatkan pula loyalitas Kepuasan memiliki pengaruh positif terhadap loyalitas dengan nilai beta yiatu 0,855 dan signifikansi terhadap loyalitas karena $p=0,000<0,05$ sehingga $\mathrm{Ha}_{5}$ diterima dimana semakin baik kepuasan pelanggan maka semakin meningkat loyalitas pelanggan.

\section{KESIMPULAN}

Berdasarkan hasil analisis dan pembahasan yang telah diurraikan maka dpaat diterik kesimpulan bahwa: 
Berdasarkan hasil analisis dan pembahasan yang telah diurraikan maka dpaat diterik kesimpulan bahwa:

1. Terdapat pengaruh yang positif dan signifikan antara promosi terhadap kepuasan pelanggan $\left(\mathrm{Ha}_{1}\right)$

2. Terdapat pengaruh positif dan signifikan antara kualitas pelayanan terhadap kepuasan pelanggan $\left(\mathrm{Ha}_{2}\right)$

3. Terdapat pengaruh positif dan tidak signifikan antara promosi terhadap loyalitas pelanggan $\left(\mathrm{HO}_{3}\right)$

4. Kualitas pelayanan berengaruh positif dan tidak signifikan terhadap loyalita spelanggan $\left(\mathrm{H}_{4}\right)$

5. Terdapat pengaruh positif dan tidak signifikan antara kualitas pelayanan terhadap loyalitas pelanggan $\left(\mathrm{H}_{5}\right)$

6. Terdapat pengaruh positif dan signifikan antara kepuasan terhadap loyalitas pelanggan ( $\left.\mathrm{Ha}_{5}\right)$

\section{DAFTRA PUSTAKA}

Amstrong, Gary \& Philip, Kotler. (2012). Dasar-Dasar Pemasaran. Jilid I, Alih Bahasa Alexander Sindoro Dan Benyamin Molan. Jakarta: Penerbit Prenhalindo. Arianto, Nurmin. (2016). Pengaruh Kaulitas Produk dan Harga Terhadap Keputusan Pemeblian Air Minum Dalam Kemasaran (AMDK) Merek Aqua. Tangerang Selatan: Jurnal Kreatif Universitas Pamulang.

Arianto, Nurmin. (2017). Pengaruh Kualitas Pelayanan, Harga dan Kepuasan Terhadap Loyalitas Pasien. Tangerang: Jurnal JOM Universitas Terbuka.

Arianto, Nurmin. (2018). Pengaruh Kualitas Produk dna Kelengkapan Produk Terhadap Keputusan Pembelian Produk Salt n Pepper Pada PT Mitra Busana Sentosa Bintaro. Tangerang Selatan: Jurnal Kreatif. Universitas Pamulang.

Buchari Alma., (2016). Manajemen Pemasaran Dan Pemasaran Jasa. Bandung. Alfabeta.

Jasfar, Farida. (2012). Kunci Keberhasilan Bisnis Jasa. Jakarta : Salemba Empat.

Kotler, P. \& Keller, K.L. (2012), Manajemen Pemasaran Jilid I Edisi Ke 12. Jakarta: Erlangga.

Sugiyono. (2013). Metodelogi Penelitian Kuantitatif, Kualitatif Dan R\&D. (Bandung: Alfabeta).

Sugiyono. (2017). Metode Penelitian Kuantitatif, Kualitatif, Dan R\&D. Bandung : Alfabeta, Cv. 